\title{
TYPES AND DENSITY OF SEAGRASS IN THE GENTING BEACH, TANJUNG MEDANG VILLAGE, RUPAT UTARA DISTRICT, BENGKALIS REGENCY, RIAU PROVINCE
}

\author{
Haini Hidayah $^{1 *}$, Muhammad Fauzi ${ }^{2}$, Adriman $^{2}$ \\ ${ }^{1}$ Student of The Faculty of Fisheries And Marine Science University of Riau, Pekanbaru \\ ${ }^{2}$ Lecturer at the Faculty of Fisheries And Marine Science University Riau, Pekanbaru \\ *haini.hidayah11@gmail.com
}

\begin{abstract}
Seagrass is present in the Genting Beach. During the low tide, however, propeler of fishermen ship damage the seagrass habitat in general. To understand the types and density of seagrass in Genting Beach, a study has been conducted in April - June 2018. There were 3 sampling points, in the river mouth of the Genting River (SP I), in the shipping line (SP II), and in the mangrove area (SP III). Seagrass were taken from 3 quadrants $(1 \times 1 \mathrm{~m})$ in each sampling point. Sampling were conducted once. The seagrass was then identified. Results shown that there was one type of seagrass species, namely Enhalus acoroides. Seagrass density range from $17.99-90.78$ organism $/ \mathrm{m}^{2}$ and the coverage of seagrass was around $3.04 \%-14.39 \%$, water temperature was $31.66-32^{\circ} \mathrm{C}$, salinity $32 \%$, $\mathrm{pH} 8$, clarity $0.26-0.33$ $\mathrm{m}$, current flow $0.37-0.42 \mathrm{~m} / \mathrm{s}$, sandy mud substrate, nitrate $0.033-0.075 \mathrm{mg} / \mathrm{L}$, phosphate $0.035-0.104 \mathrm{mg} / \mathrm{L}$ and organic material was $20.50-27.57 \%$. The seagrass density in the Genting Beach is classified as rare and the coverage as low.
\end{abstract}

Keywords : Enhalus acoroides, Density, Coverage, Seagrass

\section{PENDAHULUAN}

Lamun merupakan tumbuhan berbunga (Angiospermae) yang sudah sepenuhnya menyesuaikan diri untuk hidup terbenam di dalam laut. Tumbuhan ini terdiri dari rhizoma, daun dan akar. Dengan rhizoma dan akarnya inilah tumbuhan tersebut dapat menancapkan diri dengan kokoh di dasar laut sehingga tahan terhadap hempasan gelombang dan arus.

Ekosistem lamun atau seagrass merupakan salah satu ekosistem laut dangkal yang mempunyai peranan penting bagi kehidupan di laut serta merupakan salah satu ekosistem yang paling produktif.

Jenis lamun dipengaruhi oleh faktor tempat tumbuh dari lamun tersebut. Beberapa faktor yang mempengaruhi lamun diantaranya meliputi kedalaman, tipe substrat, kecerahan dan arus. Selain itu morfologi lamun juga berpengaruh terhadap kerapatan jenis lamun. Faktorfaktor yang dapat mempengaruhi keberadaan lamun selain substrat, yaitu pengaruh aktivitas pelayaran dan juga jangkar kapal. Berdasarkan faktor tersebut, Pantai Genting merupakan salah satu daerah yang memiliki aktivitas pelayaran yang dikarenakan mata pencaharian warga setempat selain bertani adalah menjalankan transportasi laut sebagai nelayan. Aktivitas tersebut diduga secara tidak langsung dapat mempengaruhi keberadaan lamun di kawasan tersebut.

Jenis dan kerapatan lamun di Pantai Genting Desa Tanjung Medang saat ini terdampak dari berbagai kegiatan yang ada. Pada sisi lain mengenai jenis dan 
kerapatannya belum diketahui. Berdasarkan penelitian dengan judul "Jenis dan Kerapatan Lamun di Pantai Genting Desa Tanjung Kecamatan Rupat Utara Kabupaten Bengkalis Provinsi Riau”.

Penelitian ini bertujuan untuk mengetahui jenis dan kerapatan lamun serta mengetahui kondisi parameter kualitas perairan di Pantai Genting Desa Tanjung Medang Kecamatan Rupat Utara.

\section{METODE PENELITIAN}

Penelitian ini dilaksanakan pada bulan April - Juni 2018 di Pantai Genting Desa Tanjung Medang Kecamatan Rupat Utara Kabupaten Bengkalis Provinsi Riau. Identifikasi jenis lamun dan analisis sampel sedimen dilakukan di Laboratorium Ekologi Manajemen Lingkungan Perairan Fakultas Perikanan dan Kelautan Universitas Riau.

Metode yang digunakan dalam penelitian ini adalah metode survey. Data yang digunakan dalam penelitian ini meliputi data primer dan data sekunder. Data primer diperoleh dari pengambilan sampel lamun dan pengukuran parameter kualitas air dan data sekunder diperoleh dari instansi terkait dan hasil penelitian yang pernah dilakukan.

Penentuan titik pengambilan sampel dilakukan secara purposive sampling. Sampling area pada penelitian ini terdiri dari 3 dimana pada setiap sampling area memiliki tiga transek dan masing-masing transek memilik tiga plot. Sampling Area I berada pada sekitar muara Sungai Genting, sedangkan Sampling Area II berada pada kawasan lalu lintas kapal nelayan dan Sampling Area III berada pada daerah hutan mangrove.

Identifikasi jenis lamun sementara dilakukan di Pantai Genting Desa Tanjung Medang dengan cara mencocokkan ciri-ciri morfologi lamun dengan gambar atau pustaka-pustaka yang mendukung. Kemudian divalidasi dengan melakukan kondisi tersebut, maka perlu dilakukan identifikasi kembali di laboratorium dengan cara melihat beberapa ciri-ciri morfologinya terutama pada bagian daun, ujung daun dan rhizoma.

Pengamatan kerapatan dilakukan dengan menghitung jumlah tegakan lamun dalam plot pada setiap sampling area. Kerapatan lamun dinyatakan sebagai jumlah individu/satuan luas $\left(\mathrm{m}^{2}\right)$ (Snedecor dalam Putra, 2017) dengan perhitungan :

$$
K=\sum D i / \sum n i \times A
$$

Dimana:

$$
\begin{aligned}
\mathrm{K} & =\begin{array}{l}
\text { Kerapatan lamun } \\
\end{array} \\
& \left(\text { tegakan } / \mathrm{m}^{2}\right) \\
\sum_{\mathrm{Di}} \mathrm{Di} & \text { Jumlah tegakan setiap jenis } \\
\sum_{\mathrm{A}} \mathrm{ni} & =\text { Jumlah kuadran } \\
& =\text { Luas kuadran }\left(\mathrm{m}^{2}\right)
\end{aligned}
$$

Penutupan lamun menyatakan luasan area yang tertutupi oleh tumbuhan lamun. Untuk mengetahui luas area penutupan jenis lamun tertentu dibandingkan dengan luas total area penutupan untuk seluruh jenis lamun, digunakan metode Saito dan Adobe (Kepmen LH, 2004). Adapun perhitungan penutupan jenis lamun dilakukan dengan menggunakan rumus :

$$
C=\frac{\sum(M i \times f i)}{\sum f}
$$

Keterangan :

C : Presentase penutupan jenis lamun i

Mi : Presentase titik tengah dari kelas kehadiran jenis lamun $\mathrm{i}$

f : Banyaknya sub petak dimana kelas kehadiran jenis lamun i sama

fi : Frekuensi dari kelas ke-i

\section{HASIL DAN PEMBAHASAN Keadaan Umum Lokasi Penelitian}

Desa Tanjung Medang merupakan salah satu desa yang berada dalam wilayah 
Kecamatan Rupat Utara Kabupaten Bengkalis Provinsi Riau dengan luas wilayah yaitu $66 \mathrm{~km}^{2}$. Desa Tanjung Medang terletak pada koordinat $0^{\circ} 55^{\prime} 24^{\prime \prime}$ $2^{\circ} 7^{\prime} 41^{\prime \prime}$ LU dan $101^{\circ} 25^{\prime} 43^{\prime \prime}$ - 101 ${ }^{\circ} 47^{\prime} 14^{\prime \prime}$ BT yang berbatasan langsung sebelah utara dengan Selat Malaka, sebelah timur dengan Desa Teluk Rhu, sebelah selatan dengan Desa Suka Damai dan sebelah barat berbatasan dengan Kabupaten Rokan Hilir.

\section{Jenis Lamun yang ditemukan}

Jenis lamun yang ditemukan di Pantai Genting Desa Tanjung Medang 1 jenis lamun yaitu Enhalus acoroides. Lamun jenis E. acoroides ini hidup tertanam pada substrat. Daun lamun dari jenis E. acoroides ini berbentuk seperti pita dengan tepi daun yang rata dan ujungnya tumpul. Rimpang dari lamun ini berdiameter lebih dari $1 \mathrm{~cm}$ dengan rambut hitam panjang dan akar seperti tali. Jenis lamun E. acoroides yang ditemukan di Pantai Genting Desa Tanjung Medang ini tumbuh pada substrat pasir bercampur lumpur dengan perairan yang keruh.

Menurut Arthana (2005), lamun jenis E. acoroides memiliki daun yang lebih tebal, lebar dan panjang, sehingga memiliki ruang fotosintesa yang lebih besar per individunya. Jenis E. acoroides bahkan dapat hidup mulai dari sedimen lumpur terrigenous sampai sedimen kasar karbonat, atau mulai dari salinitas rendah didekat muara sungai sampai salinitas yang relatif tinggi di pulau-pulau yang jauh dari pengaruh muara sungai (Waycott et al., 2004). Oleh karena itu, lamun jenis ini merupakan lamun yang paling tinggi tingkat kelangsungan hidupnya dari pada lamun jenis yang lain.

\section{Kerapatan Lamun}

Berdasarkan perhitungan kerapatan lamun dilokasi penelitian maka diperoleh nilai kerapatan rata-rata lamun persampling area (Tabel 1).

Tabel 1. Nilai Rata-rata Kerapatan Lamun

\begin{tabular}{|c|c|c|c|}
\hline Sampling Area & Titik Sampling & $\begin{array}{l}\text { Kerapatan per Titik } \\
\text { Sampling (ind } / \mathbf{m}^{2} \text { ) }\end{array}$ & $\begin{array}{c}\text { Kerapatan per Sampling } \\
\left.\text { Area (ind } / \mathbf{m}^{2}\right) \\
\end{array}$ \\
\hline \multirow{3}{*}{ I } & 1 & 18,33 & \multirow{3}{*}{17,99} \\
\hline & 2 & 19,33 & \\
\hline & 3 & 16,33 & \\
\hline \multirow{3}{*}{ II } & 1 & 41 & \multirow{3}{*}{46,66} \\
\hline & 2 & 41,66 & \\
\hline & 3 & 56,66 & \\
\hline \multirow{3}{*}{ III } & 1 & 97 & \multirow{3}{*}{90,78} \\
\hline & 2 & 95,33 & \\
\hline & 3 & 80 & \\
\hline
\end{tabular}

Berdasarkan Tabel 1 dapat diketahui bahwa dari 9 titik sampling pengamatan yang diletakkan di perairan Pantai Genting, masing-masing titik sampling memiliki jumlah kerapatan yang berbeda yaitu berkisar antara 16,33-97 ind $/ \mathrm{m}^{2}$. Kerapatan rata-rata jenis lamun persampling area yang tertinggi terdapat pada Sampling Area III dengan rata-rata sebesar $90,78 \mathrm{ind} / \mathrm{m}^{2}$. Kondisi ini menurut Amran dalam 
Nurzahraeni (2014) termasuk dalam skala 2 dengan nilai kerapatan $25-224 \mathrm{ind} / \mathrm{m}^{2}$ yang berarti lamun pada Sampling Area III ini tergolong pada kondisi jarang. Kerapatan terendah terdapat pada Sampling Area I dengan rata-rata $17,99 \mathrm{ind} / \mathrm{m}^{2}$ dimana kondisi pada sampling area ini termasuk dalam skala 1 dengan nilai kerapatan $<25$ ind $/ \mathrm{m}^{2}$ yang berarti lamun pada Sampling Area I ini tergolong pada kondisi sangat jarang. Sedangkan pada Sampling Area II memiliki kerapatan 46,66 ind $/ \mathrm{m}^{2}$ dimana kondisi ini termasuk dalam skala 2 dengan nilai kerapatan $25-224 \mathrm{ind} / \mathrm{m}^{2}$ yang berarti lamun pada Sampling Area II ini tergolong pada kondisi jarang.

Kerapatan jenis lamun dipengaruhi oleh faktor tempat tumbuh dari lamun tersebut diantaranya kedalaman, kecerahan, tipe substrat, arus dan suhu. Kerapatan lamun akan semakin tinggi jika kondisi lingkungan perairan tempat tumbuh lamun dalam keadaan baik. Pada lokasi penelitian faktor-faktor pembatas dari pertumbuhan lamun yang ditinjau dari parameter kualitas perairan selain disebabkan oleh faktor alami, aktivitas manusia juga memberikan dampak negatif terhadap lingkungan perairan sehingga secara tidak langsung dapat mempengaruhi ekosistem lamun.

\section{Persentase Penutupan Jenis Lamun}

Penutupan lamun menggambarkan seberapa luas lamun yang menutupi suatu perairan yang dinyatakan dalam persen. Hasil persentase penutupan lamun di lokasi penelitian dapat dilihat pada Tabel 2 .

Tabel 2. Persentase Penutupan Lamun

\begin{tabular}{|c|c|c|c|}
\hline Sampling Area & Titik Sampling & $\begin{array}{c}\text { Persentase Penutupan } \\
\text { Lamun per Titik Sampling } \\
\left.\text { (ind } / \mathrm{m}^{2}\right)\end{array}$ & $\begin{array}{c}\text { Persentase Penutupan } \\
\text { Lamun per Sampling Area } \\
\left(\text { ind } / \mathrm{m}^{2}\right)\end{array}$ \\
\hline \multirow{3}{*}{ I } & 1 & 2,75 & \multirow[t]{3}{*}{ ( } \\
\hline & 2 & 3,63 & \\
\hline & 3 & 2,75 & \\
\hline \multirow{3}{*}{ II } & 1 & 6,51 & \multirow{3}{*}{7,63} \\
\hline & 2 & 6,88 & \\
\hline & 3 & 9,51 & \\
\hline \multirow{3}{*}{ III } & 1 & 15,89 & \multirow{3}{*}{14,39} \\
\hline & 2 & 14,51 & \\
\hline & 3 & 12,76 & \\
\hline
\end{tabular}

Tabel 2 menunjukkan bahwa persentase penutupan lamun terendah ditemukan pada Sampling Area I yaitu 3,04 $\%$ dan tertinggi pada Sampling Area III yaitu $14,39 \%$. Tinggi rendahnya persentase penutupan lamun pada sampling area dipengaruhi oleh tinggi rendahnya kerapatan Jenis lamun. Rata-rata persentase penutupan pada plot 1, 2, dan 3 pada masing-masing sampling area berbeda. Dilihat dari penutupan lamun yang ditemui, Sampling Area I dan II merupakan area yang mendapat gangguan dari aktivitas manusia. Aktivitas tersebut mempengaruhi kondisi lingkungan perairan sehingga memiliki persen penutupan lamun lebih kecil. Dari aktivitas tersebut salah satunya menyebabkan kekeruhan, tentu saja secara tidak langsung berkaitan dengan intensitas cahaya yang dapat tembus ke dalam kolom air, kekeruhan yang tinggi pada suatu perairan dapat mengakibatkan banyaknya cahaya yang dipantulkan kembali oleh partikel tersuspensi sehingga intensitas cahaya matahari yang diterima oleh lamun bias dan tidak optimal sehingga akan mengganggu proses fotosintesis (Supriadi, 2003). 
Perbedaan kerapatan dan penutupan lamun pada masing-masing sampling area dapat menggambarkan bahwa penyebaran yang bervariasi, hal ini dapat diakibatkan adanya perbedaan kondisi lingkungan dan perlakuan yang diperoleh dari dua sampling area yang mewakili kawasan padat aktivitas antropogenik (nelayan dan wisata pantai) dan minim aktivitas antropogenik. Maka dari itu berdasarkan skala kondisi penutupan padang lamun oleh KepMen LH No. 200 Tahun 2004, maka masing-masing sampling area termasuk kategori miskin (rusak/buruk), sedangkan menurut

\section{Parameter Fisika dan Kimia Perairan Suhu}

Dari hasil pengukuran suhu di perairan pantai Genting berkisar antara $31,66-32{ }^{\circ} \mathrm{C}$ dimana Sampling Area I dan Sampling Area II memiliki suhu yang sama yaitu $31,66{ }^{\circ} \mathrm{C}$ sedangkan Sampling Area III $32{ }^{\circ} \mathrm{C}$. Pada setiap sampling area pengamatan, nilai suhu perairan pantai Genting masih sesuai dengan baku mutu yaitu $28-32^{\circ} \mathrm{C}$ (KEPMEN LH NO. 51 Tahun 2004). Suhu merupakan salah satu faktor yang sangat penting dalam mengatur proses kehidupan dan penyebaran organisme. Perubahan suhu terhadap kehidupan lamun dapat mempengaruhi metabolisme, penyerapan unsur hara dan kelangsungan hidup lamun.Salinitas

Nilai salinitas di perairan pantai Genting pada saat melakukan penelitian pada masing-masing titik sampling memiliki nilai yang sama yaitu 32\%o. Nilai tersebut masih sesuai dengan baku mutu salinitas untuk kehidupan lamun yaitu 3334\% (KEPMEN LH NO. 51 Tahun 2004). Hutomo (1999) dalam Hasanuddin (2013) menjelaskan bahwa lamun memiliki kemampuan toleransi yang berbeda terhadap salinitas, namun sebagian besar memiliki kisaran yang lebar yaitu 10-40\%o. Nilai salinitas yang optimum bagi lamun adalah 35\%o. Walaupun spesies lamun
Rahmawati (2014) termasuk kategori jarang.

Berdasarkan hasil penelitian Hara (2015) persentase penutupan lamun di Rupat Utara Pulau Beruk pada Stasiun I 30\%, Stasiun II 50\%, Stasiun III 30\%, Stasiun IV 10\%, dan Stasiun V 5\%. Sedangkan pada Stasiun VI tidak ditemukannya jenis lamun E. acoroides. Jika dibandingkan dengan nilai persentase penutupan pada penelitian ini (Tabel 2), kondisi tutupan lamun di Pantai Genting Desa Tanjung Medang Kecamatan Rupat Utara lebih rendah daripada tutupan lamun di Pulau Beruk.

memiliki toleransi terhadap salinitas yang berbeda-beda, namun sebagian besar memiliki kisaran yang besar terhadap salinitas yaitu 10-30\%o.

\section{Kecerahan}

Hasil pengukuran kecerahan perairan di Pantai Genting berkisar antara 0,26-0,32 m. Kecerahan terendah terdapat pada Sampling Area I yaitu 0,26 m dan tertinggi terdapat pada Sampling Area III yaitu 0,33 m. Hal tersebut menunjukkan bahwa kecerahan di perairan Pantai Genting termasuk rendah. Kecerahan yang rendah pada perairan memberikan dampak negatif bagi lamun dimana intensitas cahaya matahari tidak masuk ke perairan yang mengakibatkan proses fotosintesis menjadi terhambat. Hal ini sesuai dengan KepMen LH No. 51 Tahun 2004 bahwa baku mutu kecerahan perairan yang baik bagi lamun yaitu >3 m, dengan demikian kondisi kecerahan tergolong buruk karena cahaya matahari tidak dapat masuk melebihi baku mutu perairan sehingga tidak menyediakan cahaya matahari yang cukup untuk proses fotosintesis pada lamun.

\section{Kecepatan Arus}

Kecepatan arus pada area padang lamun di Pantai Genting berkisar antara 0,37 - 0,42 m/s. Pada Sampling Area I dan II kecepatan arus yaitu lebih dari $0,40 \mathrm{~m} / \mathrm{s}$. 
Kondisi arus tersebut tergolong relatif cepat yang disebabkan oleh faktor alami (gelombang) maupun aktivitas pelayaran. Sedangkan pada Sampling Area III kecepatan arus tergolong normal karena tidak terdapatnya aktivitas pelayaran.

\section{Kedalaman}

Hasil rata-rata pengukuran kedalaman selama penelitian pada setiap sampling area yaitu kedalaman tertinggi pada Sampling Area II yaitu $106,5 \mathrm{~cm}$ dan kedalaman terendah terdapat pada Sampling Area I yaitu $101 \mathrm{~cm}$. Kisaran kedalaman tempat lamun ditemukan merupakan perairan yang tergolong dangkal karena dibawah kedalaman 2 meter. Perbedaan kedalaman pada setiap Stasiun dapat disebabkan karena adanya perbedaan topografi dasar perairan baik pada daerah intertidal maupun subtidal, Hutabarat dan Evans (1985) menyatakan bahwa kedalaman suatu perairan sangat erat hubungannya dengan penetrasi cahaya matahari ke dalam kolom air yang digunakan oleh tumbuhan berklorofil untuk fotosintesis.

\section{Derajat Keasaman (pH)}

Nilai keasaman di Pantai Genting pada masing-masing titik sampling adalah 8. Hal ini sesuai dengan kisaran optimum berdasarkan KepMen LH No. 51 Tahun 2004 untuk baku mutu air laut dimana nilai derajat keasaman $(\mathrm{pH})$ optimum untuk pertumbuhan lamun berkisar 7-8,5. Menurut Effendi (2003) sebagian tumbuhan air akan mengalami kematian karena tidak toleransi pada kondisi keasaman perairan rendah $<4$.

\section{Jenis Substrat}

Jenis sedimen yang diperoleh dari setiap sampling area penelitian di Pantai Genting adalah lumpur dan pasir dengan nilai persentase yang berbeda-beda. Adapun persentase jenis sedimen dapat dilihat pada Tabel 3 .

Tabel 3. Persentase Fraksi Sedimen pada Setiap Sampling Area di Perairan Desa Tanjung Medang.

\begin{tabular}{ccccc}
\hline Sampling Area & Kerikil \% & Pasir \% & Lumpur \% & Jenis Sedimen \\
\hline I & 0 & 44,20 & 55,80 & Pasir Berlumpur \\
II & 0 & 24,70 & 75,30 & Lumpur \\
III & 0 & 25,15 & 74,85 & Lumpur Berpasir \\
\hline
\end{tabular}

Berdasarkan Tabel 3 jenis sedimen yang terdapat di Pantai Genting pada setiap sampling area didominasi oleh pasir dan lumpur. Penamaan jenis sedimen sesuai dengan Buchanan (1984) yaitu pada Sampling Area I jenis sedimennya adalah pasir berlumpur dimana kandungan

sedimen kurang dari $75 \%$ pasir dan lumpur diatas 25\%, pada Sampling Area II jenis sedimennya adalah lumpur dimana kandungan sedimen mengandung $75 \%$ atau lebih dari $75 \%$ lumpur dan Sampling Area III jenis sedimennya adalah lumpur berpasir dimana kandungan sedimen kurang dari $75 \%$ lumpur dan pasir diatas $25 \%$.

Menurut Arthana (2005), lamun jenis E. acoroides memiliki daun yang lebih tebal, lebar dan panjang, sehingga memiliki ruang fotosintesa yang lebih besar per individunya. Jenis E. acoroides bahkan bisa hidup mulai dari sedimen lumpur terrigenous sampai sedimen kasar karbonat, atau mulai dari salinitas rendah di dekat muara sungai sampai salinitas yang relatif tinggi di pulau-pulau yang jauh dari pengaruh muara sungai (Waycott et al., 2004). Oleh karena itu, lamun jenis ini merupakan lamun yang paling tinggi tingkat kelangsungan hidup dari pada 
lamun jenis yang lain. Dapat disimpulkan bahwa semua jenis substrat bisa ditumbuhi lamun akan tetapi pada jenis lamun $E$. acoroides tumbuh baik pada substrat yang berdominan lumpur, tentu saja dengan dukungan lingkungan perairan yang mendukung untuk kehidupan lamun.

\section{KESIMPULAN DAN SARAN}

\section{Kesimpulan}

Berdasarkan hasil yang diperoleh dari penelitian ini, maka dapat disimpulkan bahwa terdapat 1 jenis lamun yang ditemukan di perairan Pantai Genting yaitu jenis Enhalus acoroides. Kerapatan ratarata lamun persampling area berkisar antara $17,99-90,78 \mathrm{ind} / \mathrm{m}^{2}$. Persentase penutupan lamun persampling area berkisar antara $3,04 \%$ - 14,39\%. Kerapatan lamun pada Pantai Genting termasuk dalam kategori sangat jarang dan jarang, sedangkan status penutupan lamun pada Pantai Genting termasuk miskin. Kerapatan lamun jenis $E$. acoroides tertinggi terdapat pada substrat lumpur berpasir, sedangkan yang terendah terdapat pada substrat pasir berlumpur.

\section{Saran}

Perlu dilakukan kajian yang lebih spesifik di perairan Pantai Genting yang tidak hanya dilihat dari tekstur sedimen dan kualitas airnya, akan tetapi dapat dilihat dari faktor lain yang dapat berpengaruh terhadap kondisi padang lamun di perairan tersebut. Selain itu perlu dilakukannya rehabilitasi lamun berupa transplantasi guna meningkatkan persentase ekosistem lamun karena kerapatan lamun di Rupat Utara telah mengalami pernurunan kerapatan, sehingga rehabilitasi lamun pada kawasan-kawasan dengan kerapatan yang rendah perlu dilakukan untuk menambah tegakan-tegakan lamun baru sehingga dapat berfungsi sebagai habitat biota.

\section{DAFTAR PUSTAKA}

1. Arthana, I. W. (2005). Jenis dan Kerapatan Padang Lamun di Pantai Sanur Bali, Denpasar: Universitas Udayana. Jurnal Lingkungan Hidup Bumi Lestari Volume 2(5) Pages 68-76.

2. Asriyana dan Yuliana. (2012). Produktivitas Perairan (P. 300). Bumi Aksara Jakarta.

3. Buchanan, J. B. (1984). Sedimen Analisis, pp 47-48, In N.A. Holme and A. D. Mc Intyre (eds), Methods For Study Marine Benthos. Blackwell Science, Oxford.

4. Daeng, B. (2018). Keterkaitan Jenis dan Kerapatan Lamun dengan Tekstur Sedimen di Dusun Biringkassi Desa Sapanang Kecamatan Binamu Kabupaten Jeneponto. Skripsi Fakultas Ilmu Kelautan dan Perikanan Universitas Hasanuddin. Makassar. 43 hal. (tidak diterbitkan)

5. Effendi, H. (2003). Telaah Kualitas Air Bagi Pengelolaan Sumber Daya dan Lingkungan Perairan. Penerbit Kanisius. Yogyakarta.

6. Hara, F. (2015). Pola Distribusi dan Kerapatan Lamun di Perairan Pulau Beruk Rupat Utara Kabupaten Bengkalis Provinsi Riau. Skripsi Fakultas Perikanan dan Kelautan Universitas Riau. Pekanbaru.

7. Hasanuddin, R. (2013). Hubungan Antara Kerapatan dan Morfometrik Lamun Enhalus acoroides dengan Substrat dan Nutrien di Pulau Sarappo Lompo Kab. Pangkep. Skripsi Jurusan Ilmu Kelautan. Fakultas Ilmu Kelautan dan Perikanan Universitas Hasanuddin. Makassar.

8. Hutabarat dan Evans. (1985). Pengantar Oseanografi. Penerbit Universitas Indonesia. UIPress. 
9. Keputusan Menteri Negara Lingkungan Hidup. (2004). Daftar Peraturan Perundangan Lingkungan Hidup Kerusakan dan Pedoman Penentuan Status Padang Lamun. Keputusan Menteri Negara Lingkungan Hidup Nomor 200 Tahun 2004. Jakarta.

10. Keputusan Menteri Negara Lingkungan Hidup. (2004). Baku Mutu Air Laut Untuk Biota Laut. Keputusan Menteri Negara Lingkungan Hidup Nomor 51 Tahun 2004.

11. Nurzahraeni. (2014). Keragaman Jenis dan Kondisi Padang Lamun di Perairan Pulau Panjang Kepulauan Derawan Kalimantan Timur. Skripsi Jurusan Ilmu Kelautan. Fakultas Ilmu Kelautan dan Perikanan. Universitas Hasanuddin. Makassar.

12. Putra, I. A. (2017). Potensi Penyimpanan Karbon Pada Lamun (Cymodocea serrulata) di Perairan Pulau Poncan Sibolga Provinsi Sumatera Utara. Skripsi Fakultas Perikanan dan Kelautan. Universitas Riau. Pekanbaru.

13. Rahmawati, S., A. Irawan., I. H. Supriyadi dan M. H. Azkab. (2014). Panduan Moniroting Padang Lamun (P. 32). COREMAP CTI LIPI: Jakarta.

14. Supriadi. (2003). Produktivitas Lamun Enhalus acoroides (Linn. F) Royle dan Thalassia hemprichii di Pulau Barranglompo Makassar. Tesis Fakultas Perikanan dan Ilmu Kelautan. Institut Pertanian Bogor. Bogor.

15. Tuwo, A. (2011). Pengelolaan Ekowisata pesisir dan Laut. Brilian Internasional. Sidoarjo.

16. Wajdiah. (2017). Jenis dan Kerapatan Lamun Hubungannya dengan Kondisi Substrat di Perairan Pulau Sarappo Lompo Kabupaten Pangkep. Skripsi Departemen Ilmu Kelautan. Fakultas Ilmu Kelautan dan Perikanan Universitas Hasanuddin Makassar.

17. Waycott, M., K. Mc Mahon., J. Mellors., A. Calladine and D. Kleine. (2004). A Guide to Tropical Seagrasses of the Indo-West Pacific. James Cook University, TownsvilleQueensland-Australia.

18. Zarfen. (2017). Hubungan Parameter Kualitas Perairan Terhadap Kerapatan Lamun Di Perairan Desa Kelong Kecamatan Bintan Pesisir Kabupaten Bintan Provinsi Kepulauan Riau. Skripsi. Fakultas Ilmu Kelautan dan Perikanan Universitas Maritim Raja Ali Haji. 